Proc. Indian Acad. Sci. (Earth Planet. Sci.), Vol. 105, No. 2, June 1996, pp. 173-189.

(C) Printed in India.

\title{
Nature of the Moyar and Bhavani shear zones, with a note on its implication on the tectonics of the southern Indian Precambrian shield
}

\author{
$\mathrm{K} \mathrm{NAHA}^{1}$ and R SRINIVASAN ${ }^{2}$ \\ ${ }^{1}$ Department of Geology and Geophysics, Indian Institute of Technology, Kharagpur 721302 , \\ India \\ ${ }^{2}$ National Geophysical Research Institute, Hyderabad 500007 , India
}

MS received 30 October 1995; revised 19 April 1996

\begin{abstract}
The Moyar, Bhavani and Palghat-Cauvery shear zones have figured prominently in tectonic and metamorphic syntheses in the southern Indian Precambrian shield. Implicit in these studies is the assumption that in the Moyar shear zone in particular, transport has a large strike-slip component, with a dextral displacement of as high as $70 \mathrm{~km}$. Detailed structural investigations in several key sectors and reconnaissance over a large terrane cast doubt on several aspects of the accepted tectonic model. Both the Moyar and the Bhavani shear zones are steeply-dipping thrusts, with the Moyar shear in particular characterized by a predominantly dip-slip transport. Such a movement on a subvertical plane striking EW could in no way rotate the northerly 'trends' to EW ones as believed by many workers. Further, the Moyar and Bhavani shear zones are neither as extensive nor as pervasive as envisaged. Veering of the 'trends' in southern Karnataka, northern Tamil Nadu and northern Kerala is an inherent feature of the superposed fold systems here. Isoclinal folds with axial planes of diverse attitudes, overprinted by upright folds of varying tightness, have resulted in this change in 'trend'.
\end{abstract}

Keywords. Bhavani; Moyar; shear zones; southern India; tectonics.

\section{Introduction}

With Holmes' original suggestion in 1949 that 'orogenic trends' can be used for correlating or differentiating diverse Archaean terranes in Peninsular India, 'trends' have been used by various workers in tectonic analysis as well as in suggesting crustal evolution in southern India in particular. This tendency has continued up until this date in spite of Fermor's (1950) note of caution and Naha's (1964) critique of this concept. In the southern Indian Precambrian shield, the so-called Dharwar 'trend' of NNW changes to ENE-WSW south of Mysore. Narayanaswami (1970) suggested a superposition of orogenies for this variation. However, in their pioneering study mainly on the basis of remote sensing data, Drury et al $(1980,1984)$ have suggested that the north-northwesterly trend in the Dharwar terrane veers to nearly EW trend south of Gundlupet, because of rotation near a major shear - the Moyar shear zone (figure 1). A displacement of as high as $70 \mathrm{~km}$ effective across a zone of more than $20 \mathrm{~km}$ was envisaged, although no single study to date has provided internal evidence regarding the net slip directions on this shear zone. Implicit in this tectonic picture is the assumption of a very large strike-slip component in the Moyar shear zone which strikes nearly EW. Another shear zone sub-parallel to the Moyar shear - the Bhavani shear zone roughly along the Bhavani river - was also suggested. The two shear zones are supposed to merge near Bhavanisagar (Drury et al 1984). The tectonic model of Drury 


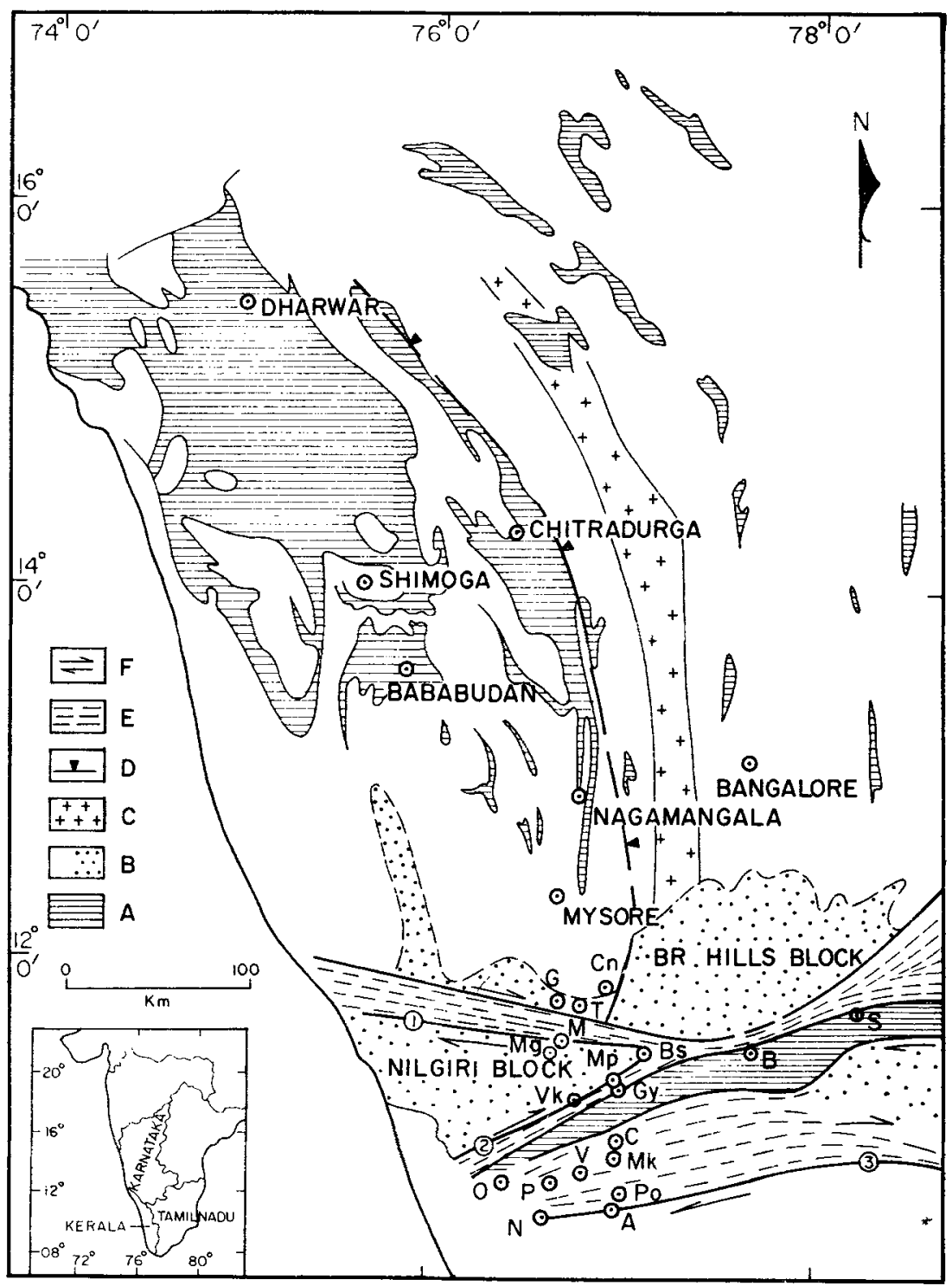

Figure 1. Tectonic map of parts of Karnataka - Tamil Nadu -- Kerala (modified from Drury et al 1984). A - Archaean supracrustal rocks; B - Archaean gneiss/granulite; $\mathbf{C}$ - granitoid plutons; D - Archaean thrust; $\mathbf{E}$ - shear zones (Late Proterozoic labrics); $\mathbf{F}$ - regional movement in Late Proterozoic(?). 1 - Moyar shear; 2 -Bhavani shear; 3 -Palghat-Cauvery shear. Localities: A-Anaimalai; B-Bhavani; Bs-Bhavanisagar; C-Coimbatore; Cn-- Chamarajnagar; G-Gundlupet; Gy-Gudaiyur; $\mathbf{M}$ - Moyar; $\mathbf{M g - M a s n i g u d ;}$ Mk-Madukkarai; Mp-Mettupalaiyam; N-Nemmara; O-Ottapalam; P - Palghat; Po-Pollachi: S - Salem; T - Terakanambi; V - Valayar; Vk -- Velliyankadu.

et al (1984) has been followed by a number of geologists without furnishing any structural detail (Radhakrishna i989; Raith et al 1990, p. 341-342; Ramakrishnan 1993). 
Our reconnaissance studies over a large terrane in Karnataka, Tamil Nadu and Kerala, with detailed structural work in a number of key sectors during more than a decade, cast doubt on some aspects of this tectonic model.

\section{Structures in the Moyar and the Bhavani shear zones}

The Moyar-Bhavani shear zones were examined from near Masnigudi and Velliyankadu in the west to Salem in the east for a length of about $120 \mathrm{~km}$; a width of $10 \mathrm{~km}$ to the north and more than $10 \mathrm{~km}$ to the south was covered. A major part of these areas is occupied by migmatitic gneisses with small enclaves of amphibolite and pyroxene granulite, so that no regional map, throwing light on the problem in question, can be prepared. Mesoscopic and microscopic studies of the rocks from these zones lead us to the following conclusions.

\subsection{Moyar shear zone}

- The Moyar shear zone is neither as extensive nor its effect as pervasive as formerly believed. The zone supposed to have been affected by shearing exposes dominantly quartzofeldspathic gneisses, with inclusions of quartzite, kyanite-quartz schist, amphibolite and pyroxene granulite. The most intense shearing is restricted to a maximum width of $2 \mathrm{~km}$ on either side of the Moyar river. Beyond this zone discrete shear planes have been observed locally. Within the shear zone itself it is the quartzofeldspathic gneiss which provides evidence of the intense deformation that the rocks have

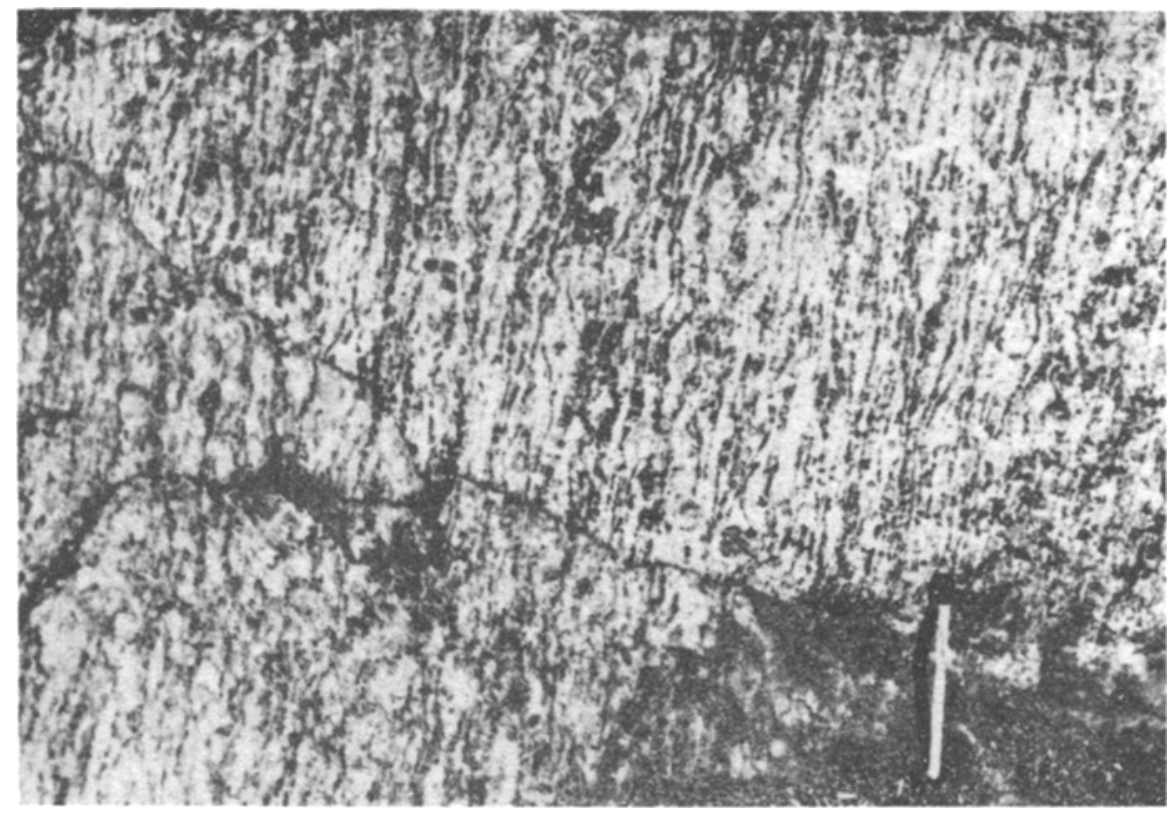

Figure 2. Mylonitic gneiss at Moyar, showing augen structure in a vertical section normal to foliation but parallel to stretching lineation. 
undergone. The pyroxene granulites and amphibolites have been sheared marginally. A typical mylonitized granite gneiss shows very thin banding with augen structure (figure 2). In thin section the augen are found to be composed of ovoidal feldspar

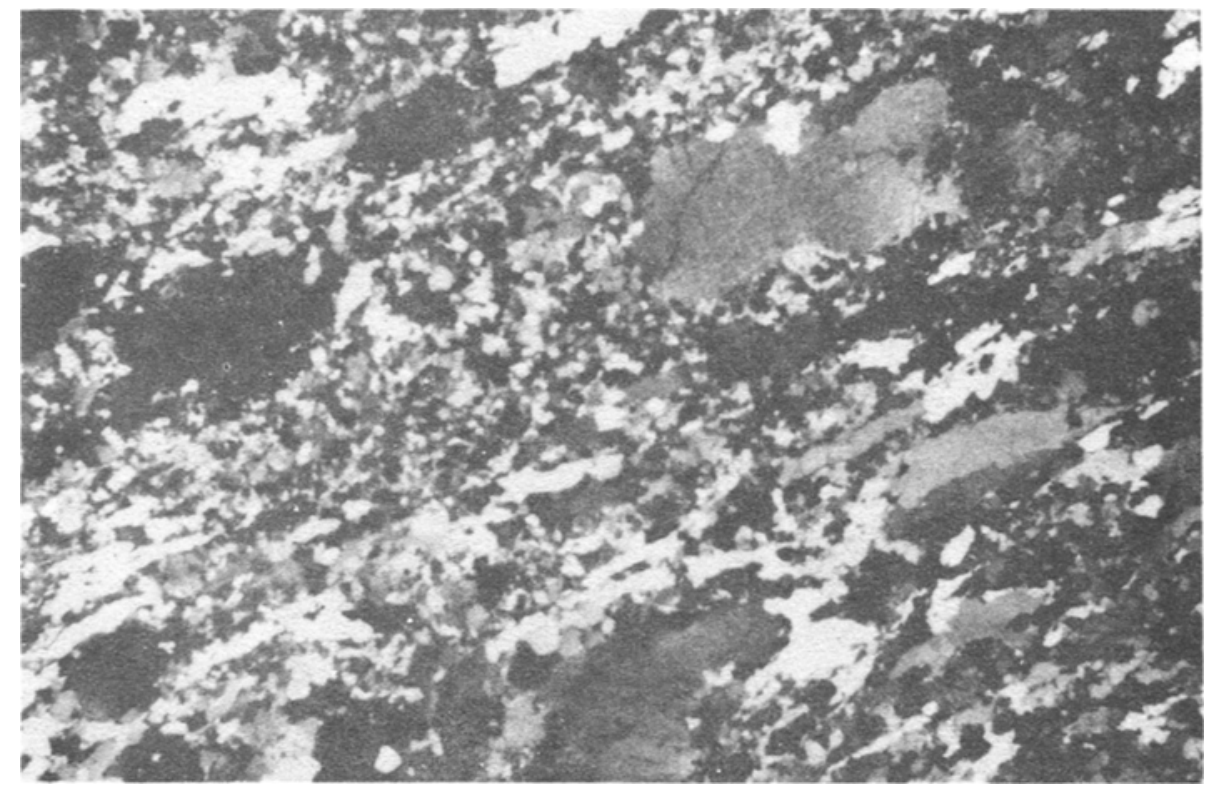

Figure 3. Photomicrograph of mylonitic gneiss from Moyar, with relict quartz-feldspar augen rimmed by recrystallized quartz in section perpendicular to foliation and parallel to stretching lineation. Crossed polarizers, $1 \cdot 2 \mathrm{~cm}$ across.

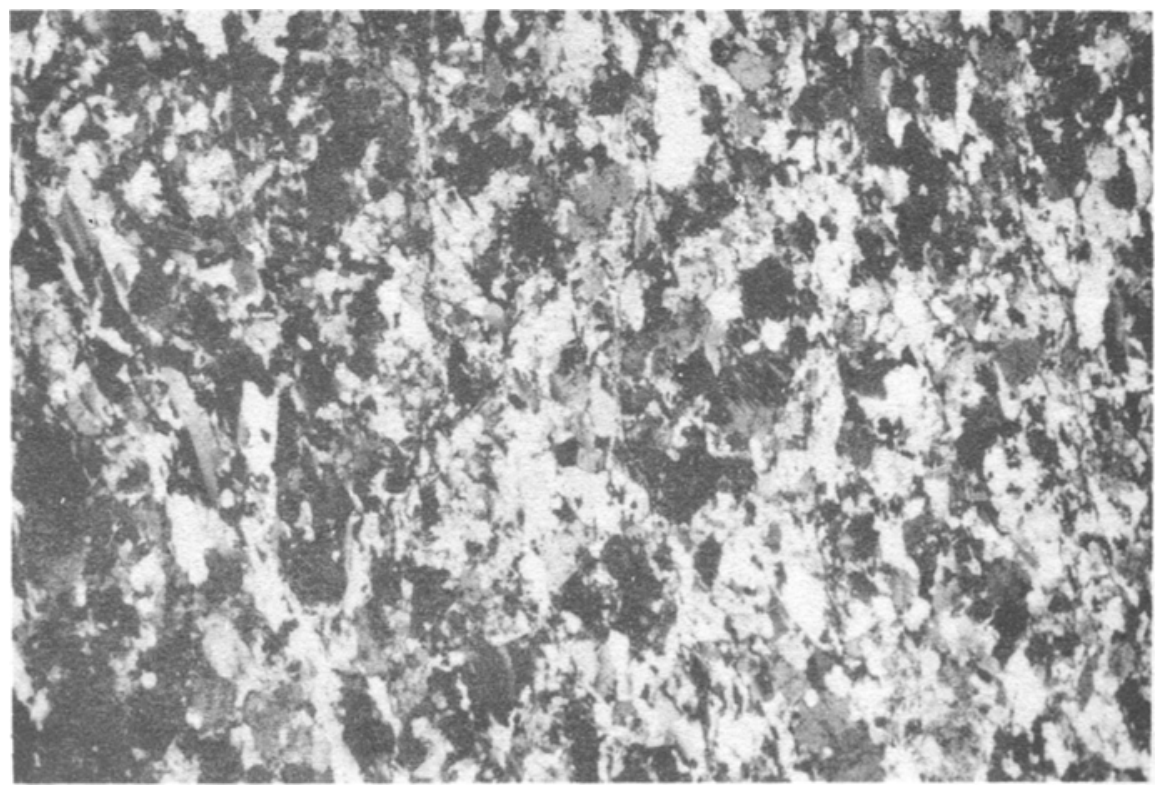

Figure 4. Photomicrograph of partly recrystallized mylonitic gneiss from the Moyar shear zone. Crossed polarizers, $1.2 \mathrm{~cm}$ across. 
porphyroclast(s) with bent and faulted twin lamellae, and with a rim of smaller recrystallized(?) grains (figure 3). They are rimmed by flat lenticular or ribbon-shaped quartz grains which flow around the porphyroclasts. Thin seams of biotite or ferruginous stains mark the shear planes. In some instances, these protomylonites give place to mylonites with very few porphyroclasts rimmed by a large number of smaller recrystallized grains (figure 4; cf. Wise et al 1984).

- As seen from figure 5(a), the shear planes are steep to vertical, dipping dominantly southward, with strike ranging from $N 70^{\circ}$ to $\mathrm{N} 110^{\circ}$. In a number of instances this variation in orientation can be proved to be due to acute folding. Without exception the slip directions show a range in pitch from $60^{\circ}$ to $90^{\circ}$ on the shear planes, a large
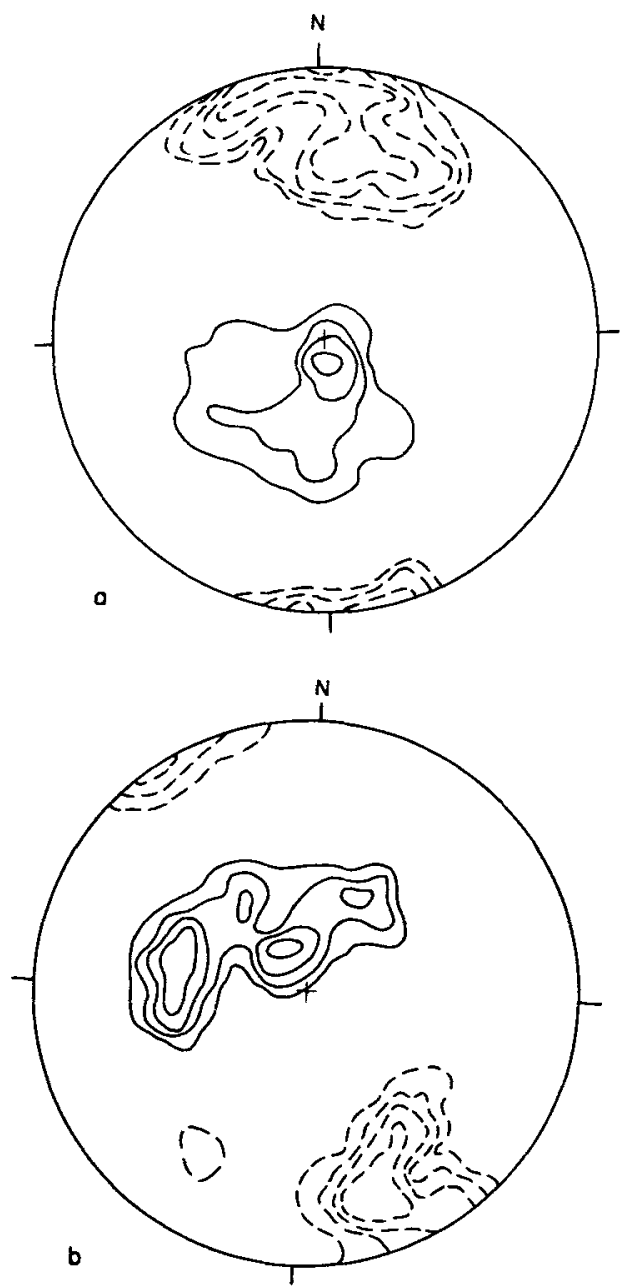

Figure 5. Lower hemisphere, equal-area projection of shear planes and linear structures in the Moyar and Bhavani shear zones. Continuous contours are linear structures and discontinuous contours are poles of $s$-planes. (a) Moyar shear zone - 60 linear structures, contours: 2-7-15-25\% per $1 \%$ area; 67 s-poles, contours: $2-3 \cdot 5-6 \cdot 5-9 \%$ per $1 \%$ area. (b) Bhavani shear zone -43 linear structures, contours: $3-6-9-13 \%$ per $1 \%$ area; 39 s-poles, contours: 3 $6-9-13 \%$ per $1 \%$ area. 
number of them being down-dip. This direction is marked by striae, slickenlines, and mineral lineations traced by quartz-feldspar slivers and streaks of biotite clots. These are stretching lineations as proved by boudins in quartzofeldspathic layers in sections normal to shear planes and parallel to lineation, and tensional joints normal thereto (figure 6). The tight folds mentioned above are, therefore, nearly reclined in attitude. That flattening has been an important component of deformation in the Moyar shear zone is shown by the ribbon quartz parallel to s-planes (figure 7), and in some instances by boudins in quartzofeldspathic layers in two directions parallel and perpendicular to lineation on the foliation plane. In such situations lineation becomes less prominent. - In sections parallel to lineation and normal to shear plane, the sense of movement determined from asymmetric folds in quartzofeldspathic bands in a few instances suggests that the southern side forming the hanging wall has moved up by thrusting (figure 8). Ridges and grooves on slickenside surfaces provide supporting evidence.

- Wide variation in strikes of foliation from NNE to SE and mesoscopic folds on sub-horizontal axes have been noted in the quartzofeldspathic gneisses within $4 \mathrm{~km}$ of the Moyar village, where the deformation is most intense. Retention of early structures. even within $4 \mathrm{~km}$ of the Moyar shear goes against the shear zone extending for $20 \mathrm{~km}$ in width.

- Any suggestion of change in 'trend" due to movement along the Moyar shear zone is untenable on two counts: (i) If the nearly NS trend southwest of Chamarajnagar was dragged into EW trend because of the Moyar shear, the $S$ to SSE trend from Sargur southward should have been reoriented through $\mathrm{S}, \mathrm{SW}$ and $\mathrm{EW}$ trend, not through $\mathrm{SE}$ to EW trend as observed south of Gundlupet. (ii) Further, a sub-vertical EW-striking slip plane, with sub-vertical slip direction cannot drag a nearly NS-striking steep plane into an EW orientation.

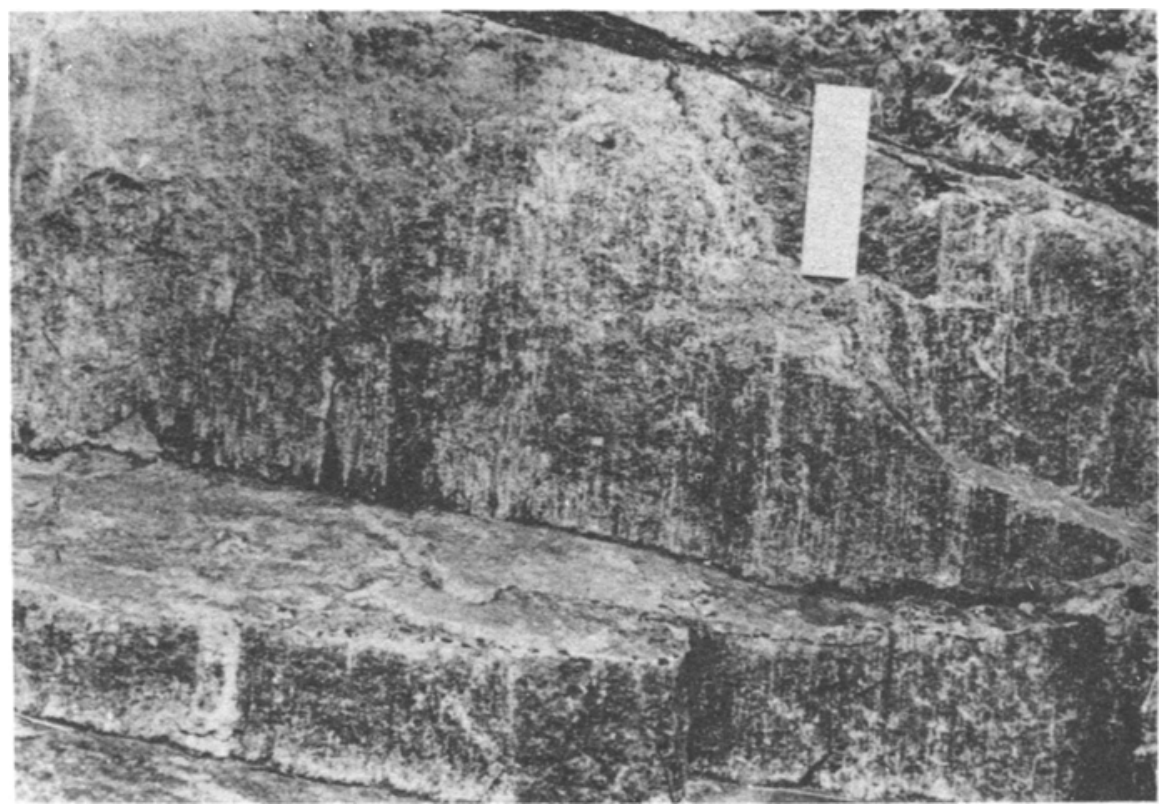

Figure 6. Stretching lineation plunging down the dip of vertical shear planes (parallel to scale) in the Moyar shear zone. Horizontal tensional joints normal to lineation noticeable. 


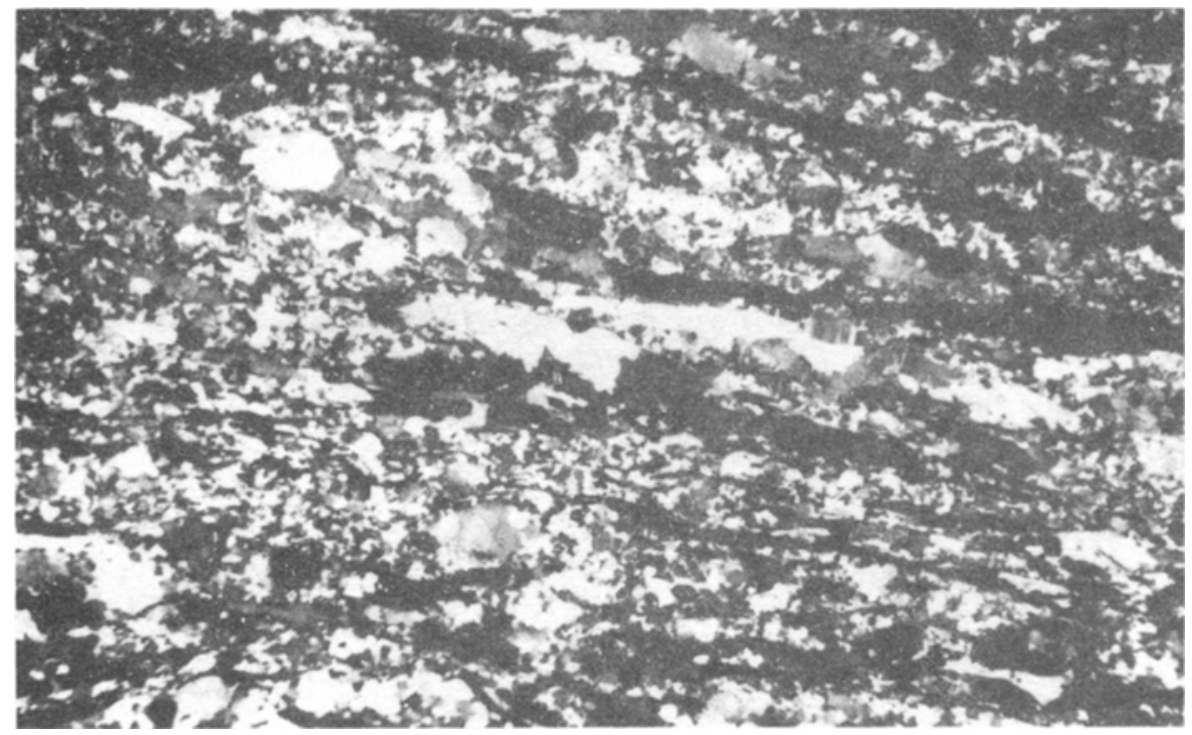

Figure 7. Photomicrograph of mylonitic gneiss from the Moyar shear zone, with ribbon quartz seen in section perpendicular to stretching lineation. Crossed polarizers, $3 \mathrm{~cm}$ across.

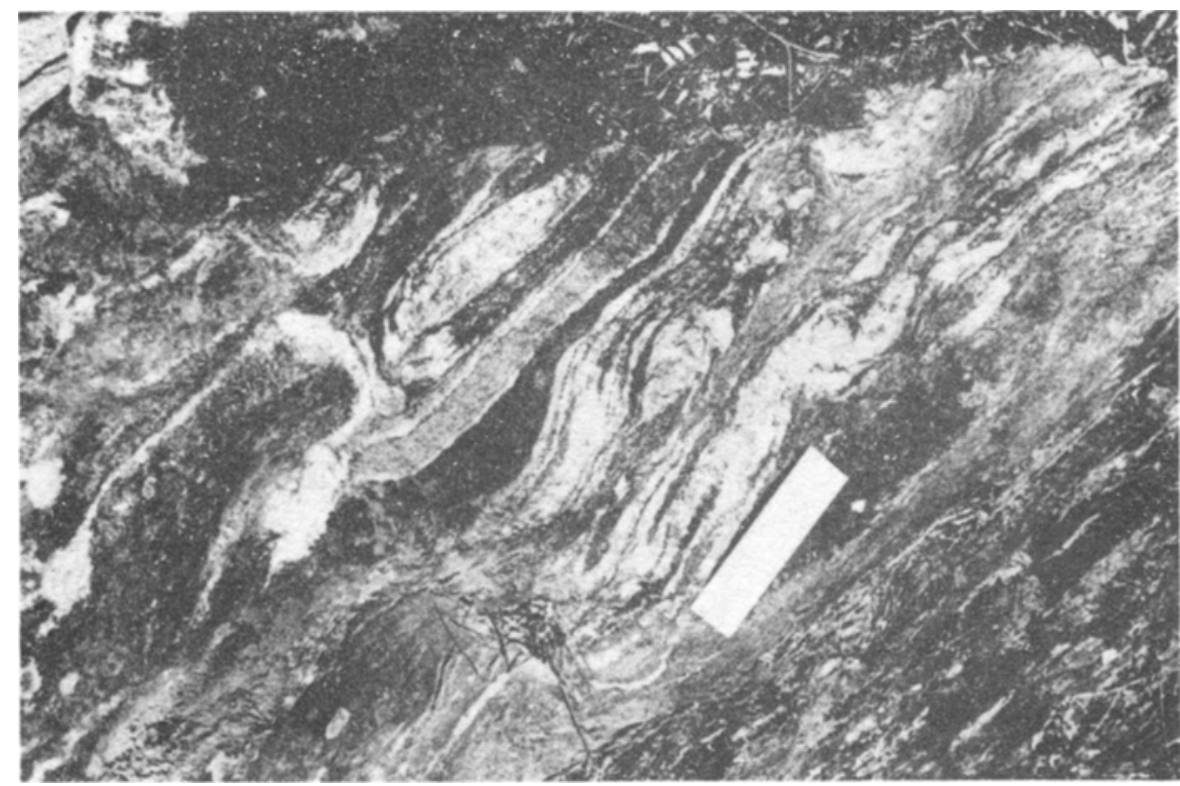

Figure 8. Subvertical section normal to foliation in migmatitic gneiss in the Moyar shear zone, with asymmetric folds indicating that the hanging wall has moved up relative to the footwall.

\subsection{Bhavani shear zone}

m The Bhavani shear zone extends up to a maximum of $2 \mathrm{~km}$ width south of Mettupalaiyam. Even within this zone, the shearing is not penetrative, so that the 
pyroxene granulites even within this zone have remained massive at places. In some instances, however, they have been transformed into hornblende biotite gneisses. As in the Moyar shear zone, here also the quartzofeldspathic gneisses register the effect of shearing best. All stages of deformation-recrystallization from protomylonite, through mylonite to ultramylonite have been noted in the quartzofeldspathic rocks in particular (figures 9 and 10). In the protomylonites large porphyroclastic ovoids of feldspar (microcline and plagioclase) and quartz, with the major axes lying on mylonitic foliation are surrounded by small polygonal, equant quartz-feldspar grains. The porphyroclasts have sutured grain borders, show strong undulose extinction and bent twin lamellae in feldspar, and are often wrapped by thin ribbons of undulant quartz. Some large microcline porphyroclasts show extreme undulose extinction, fracturing with subgrain formation, and are rimmed by fine granules. With decrease in the proportion of porphyroclasts, the rocks grade into typical mylonites with a few ovoidal, fractured feldspar grains enveloped by ribbons of quartz. They finally grade into augen gneiss/schist made up of equant polygonal recrystallized quartz and feldspar, with a few relict feldspar porphyroclasts. Clusters of biotite flakes along the mylonitic foliation have individual grains sharply crystallized in sheafs, pointing to crystallization outlasting deformation.

- Where there is no post-shear mesoscopic folding, the shear planes dominantly dip northward between $60^{\circ}$ and $80^{\circ}$; the pitch of the slip directions range from $60^{\circ}$ to $90^{\circ}$ (figures $5 \mathrm{~b}$ and 11 ). The strikes of shear planes are most dominantly $\mathrm{N} 60^{\circ}$ to $\mathrm{N} 70^{\circ}$. The lineations marking the directions of slip in the shear planes are striations on discrete slickenside surfaces, and mineral lineations marked by hornblende-biotite in hornblende gneisses, and quartz-feldspar slivers in quartzofeldspathic rocks. By using the same criteria as in the Moyar shear zone, they can be proved to be stretching lineations.

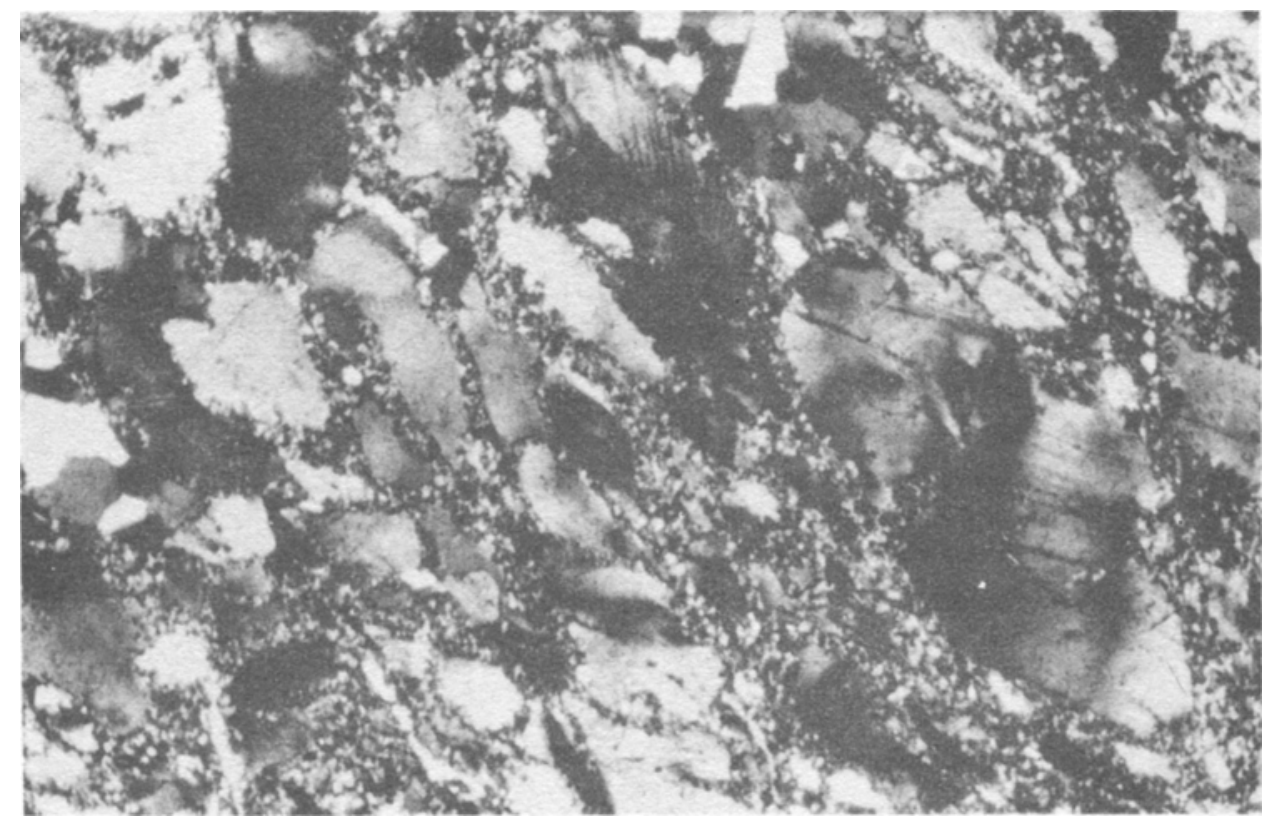

Figure 9. Protomylonite from the Bhavani shear zone near Gudaiyur, with a number of porphyroclasts of feldspar-quartz in a recrystallized base. Crossed polarizers, $3.5 \mathrm{~mm}$ across. 


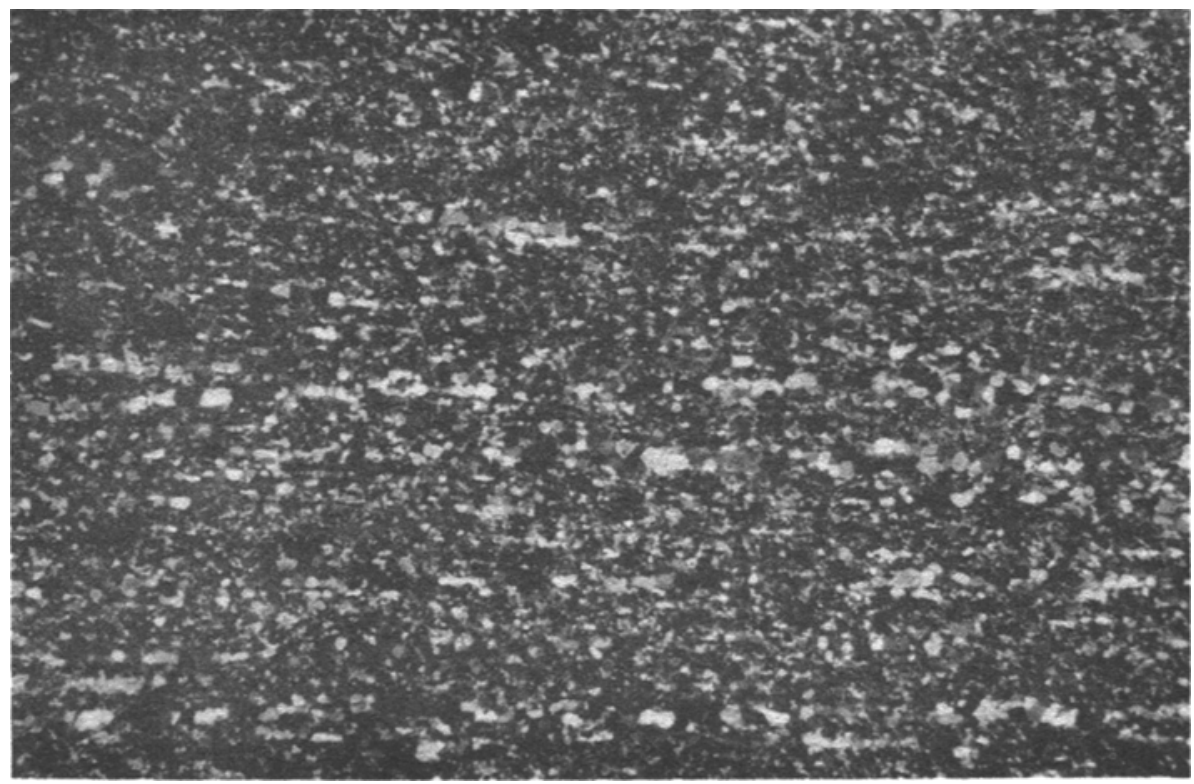

Figure 10. Mylonite from near Gudaiyur with quartz and feldspar totally recrystallized. Crossed polarizers, $1 \cdot 2 \mathrm{~cm}$ across.

The movement in the Bhavani shear zone is thus in the nature of oblique-slip (cf. Drury et al 1984), with the dip-slip component dominant.

- Flattening as an essential component of deformation in the Bhavani shear zone can be proved by the following features: (i) In a number of instances the quartzofeldspathic layers in the gneisses show boudins in two directions on the s-planes parallel and perpendicular to lineation. (ii) On the shear surfaces, the quartz-feldspar clots are flattened. (iii) Small inclusions of relict basic rocks, often reconstituted to hornblendebiotite schist, invariably have their smallest dimension normal to the shear planes. In all these instances planar structures dominate over linear features in the rocks.

- From Bhavanisagar to Bhavani for a stretch of about $50 \mathrm{~km}$ along the supposed thrust zone exposures are scanty. From Bhavani to west of Salem for about $50 \mathrm{~km}$, migmatites with small enclaves of amphibolite and pyroxene granulite invariably show isoclinal folds involved in coaxial and/or non-coaxial open folding (figure 12), so that no unique 'trend' is discernible. No perceptible effect of shearing is present. However, about $10 \mathrm{~km}$ west of Salem, isoclinally folded migmatites have been further flattened and mylonitized, with shears parallel to axial planes (figure 13). Here, as well as near Bhavani, reclined folds in these sheared granite gneisses have their axes parallel to the slip direction. Curving of the fold hinge lines on the shear surfaces suggests that the axes of original gently-plunging overturned folds, with the axial planes parallel to the slip planes in the shear zone, have been rotated towards the stretching direction in the zone of intense strain (figure 14; cf. Ghosh and Sengupta 1987).

- In a number of instances the shear planes and the mylonitic foliation have been involved in folding in mesoscopic scale on gently plunging axes, so that both the slip planes and the slip directions are disoriented now (figure $5 \mathrm{~b}$ ). Impeded transport due to increasing resistance in the waning phase of shearing is thought to have been responsible for the generation of these folds. 


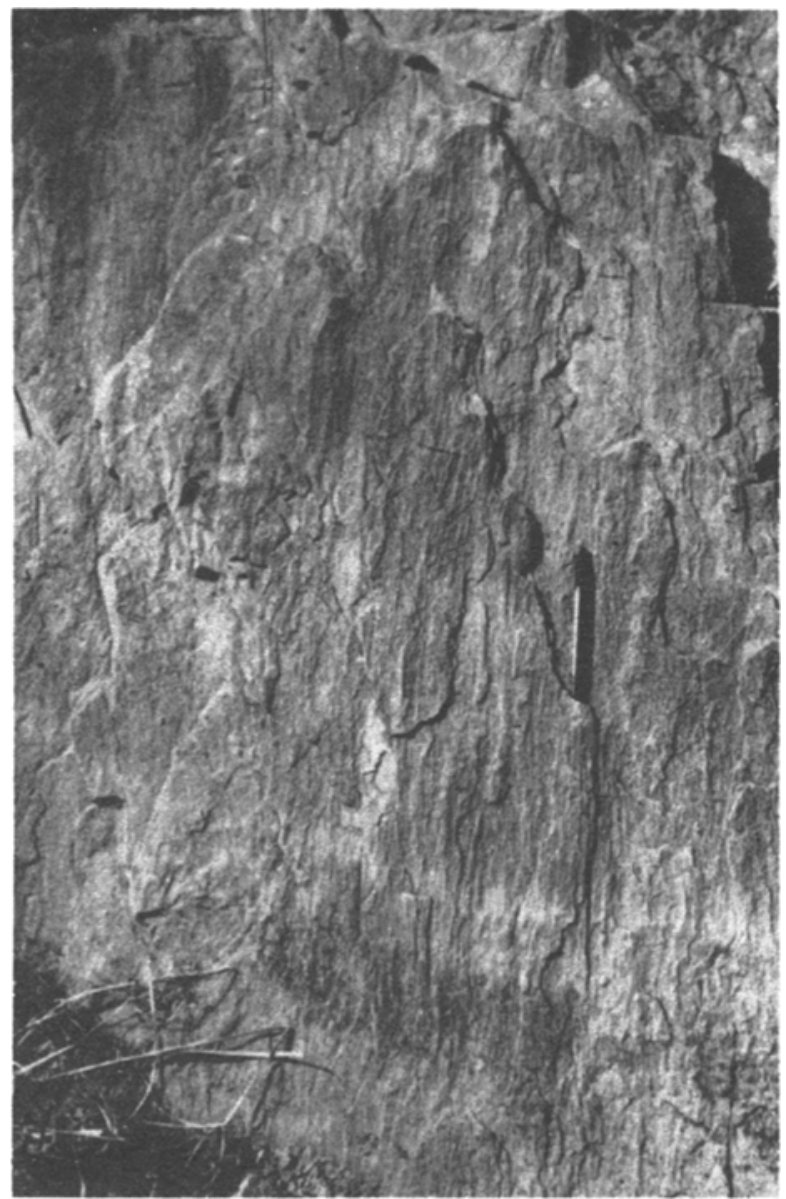

Figure 11. Down-dip lineation on sub-vertical shear surface in the Bhavani shear zone near Gudaiyur. Subhorizontal tensional joints noticeable in the top right corner.

It may be noted in this context that the supposed presence of a third shear zone - the Palghat-Cauvery shear zone (Drury et al 1984) - in the southern border of the 'Palghat gap' is suspect. Traverses from Coimbatore southward up to Anaimalai and westward up to south of Ottapalam have failed to show any effect of intense shearing as one approaches the hill ranges to the south. The general style of NE to ENE trending isoclinal folds involved in coaxial refolding is seen in the rocks of this terrane (cf. Nair and Nair 1980). At a number of places, small to large enclaves of pyroxene granulite in various stages of transformation to biotite gneiss have been noted. No positive correlation between transformation of charnockite to hornblende-biotite gneiss and shearing can be inferred. Migmatization has been the primary cause for this transformation. However, at some places like Gudaiyur this transformation is attended by shearing also.

Another point which has to be emphasized here is that neither the northern nor the southern boundary of the Palghat gap is straight. Even if we neglect a number of high topographical features marked by the presence of pyroxene granulite, marble and calc gneiss within the Palghat gap (e.g., near Ottapalam, Valayar and Madukkarai), the low 


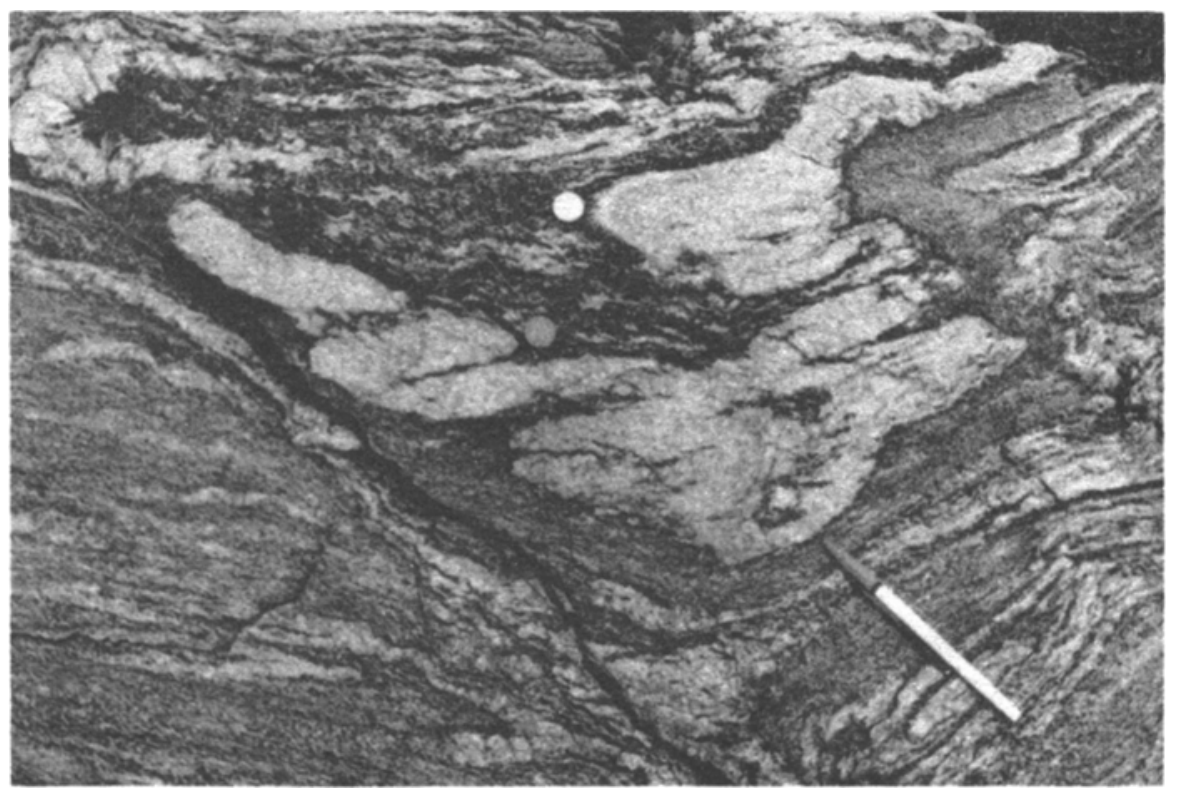

Figure 12. Type 2 interference pattern of Ramsay in migmatitic gneiss with coins near the hinge zones of two early folds. Horizontal surface, about $49 \mathrm{~km}$ west of Salem on NH47.

ground is bordered by a tortuous boundary which has been controlled by plunging folds affecting resistant beds.

\section{Implications on regional tectonics}

The Moyar and the Bhavani shear zones in the southern Indian shield have often been used for tectonic and metamorphic interpretations on the assumption that there was a large strike-slip component during movement along these shear zones. So much so, that the two charnockite massifs, the Nilgiri and the Biligiri Rangan blocks, were thought to have been shifted laterally by $70 \mathrm{~km}$ along the Moyar shear (Drury et al 1984; Raith et al 1990, p. 341-342). The foregoing details prove that neither of these two shear zones is a strike-slip one. Whereas the Bhavani shear zone shows an oblique-slip movement, with a large component of dip-slip (pitch of slip direction on the slip planes ranging from $60^{\circ}$ to $90^{\circ}$ ), the Moyar shear zone is essentially a dip-slip one. This runs counter to the possibility of the Moyar shear zone having dragged the NS-trending structures to EW orientation. The Nilgiri block appears to have been upthrust between the southerly (or vertically) dipping Moyar shear zone and the northerly dipping Bhavani shear zone. Whereas strike-slip faulting along the Moyar shear zone would imply that the intermediate compressive stress during faulting was vertical and preclude any uplift of the Nilgiri hills as many workers implicitly suggest, an essentially dip-slip movement (with thrusting accompanied by uplift of the hanging wall) would require an essentially $\mathrm{N}-\mathrm{S}$ horizontal compression. This deformational picture would explain many features pointing to a compression almost normal to the Moyar and Bhavani shear zones seen in this terrane. The high pressure granulites of the Nilgiri 


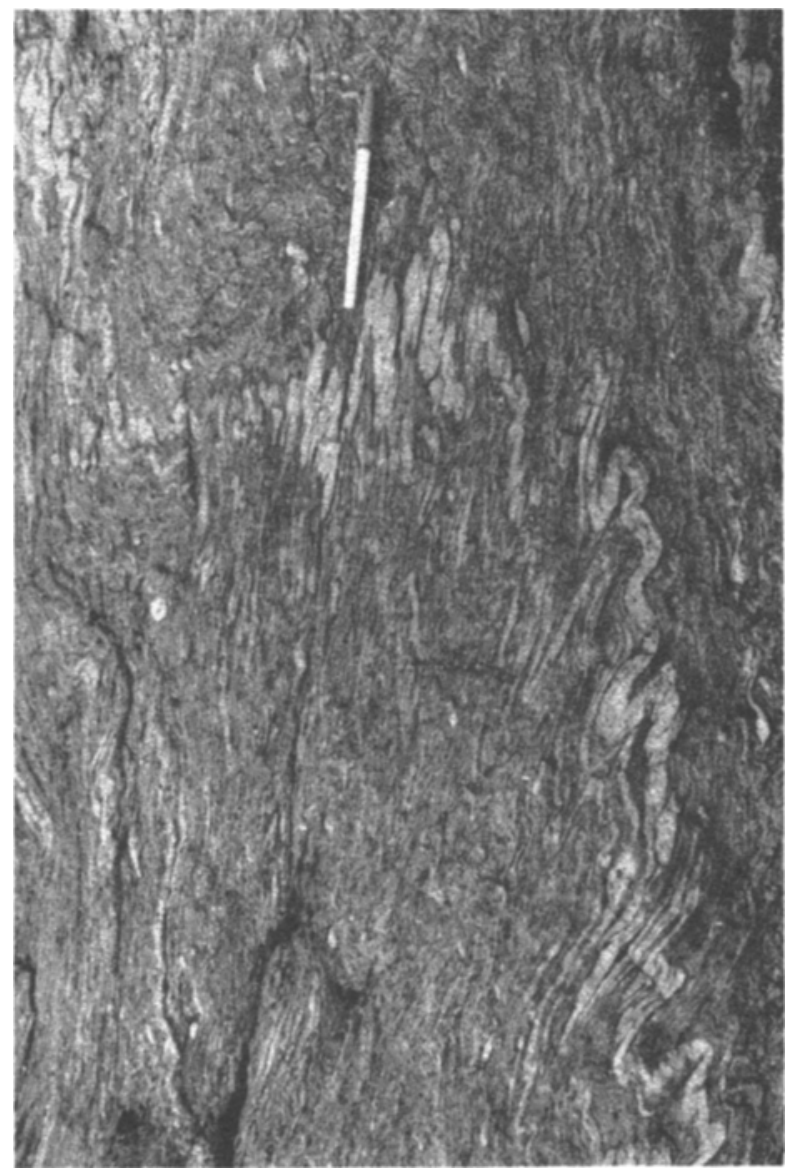

Figure 13. Mylonitized migmatitic gneiss showing isoclinal folds on steep axes disrupted by shear planes. Horizontal surface, $12.5 \mathrm{~km}$ west of Salem on NH47.

block juxtaposed against the amphibolite facies rocks along the Moyar shear as suggested by Raith et al (1990) also find an elegant explanation in this tectonic picture.

The Moyar and Bhavani shear zones cannot therefore be the cause of a gradual change in 'trend' from NS to EW in southern Karnataka and northern Tamil Nadu; the reason has to be sought elsewhere. It has been demonstrated from all supracrustal belts in the Dharwar terrane that the north-northwesterly 'Dharwar orogenic trend' represents the strike of axial planes of folds of the second generation (Naha et al 1986, 1990, 1991; Mukhopadhyay 1986). The dominant foliation and the axial planes of the isoclinal folds of the first generation $\left(\mathrm{DhF}_{1}\right)$ in both the supracrustal rocks and in the Peninsular Gneiss have been affected by near-coaxial open folding $\left(\mathrm{DhF}_{1 a}\right)$ at some places and non-coaxial upright folding extensively $\left(\mathrm{DhF}_{2}-\mathrm{Naha}\right.$ et al 1986, 1990, 1991; cf. Chadwick et al 1978; Janardhan et al 1979; Mukhopadhyay 1986). As mentioned by Naha et al (1986), the map patterns of the supracrustal belts (and hence the 'trends') are largely guided by the tightness of $\mathrm{DhF}_{2}$ folds. Variation in the 'trend' from NNW as seen in the Bababudan and Shimoga belts is due to open $\mathrm{DhF}_{2}$ folding. The dominant NNW trend swings to nearly EW trend south of Mysore. In contrast 


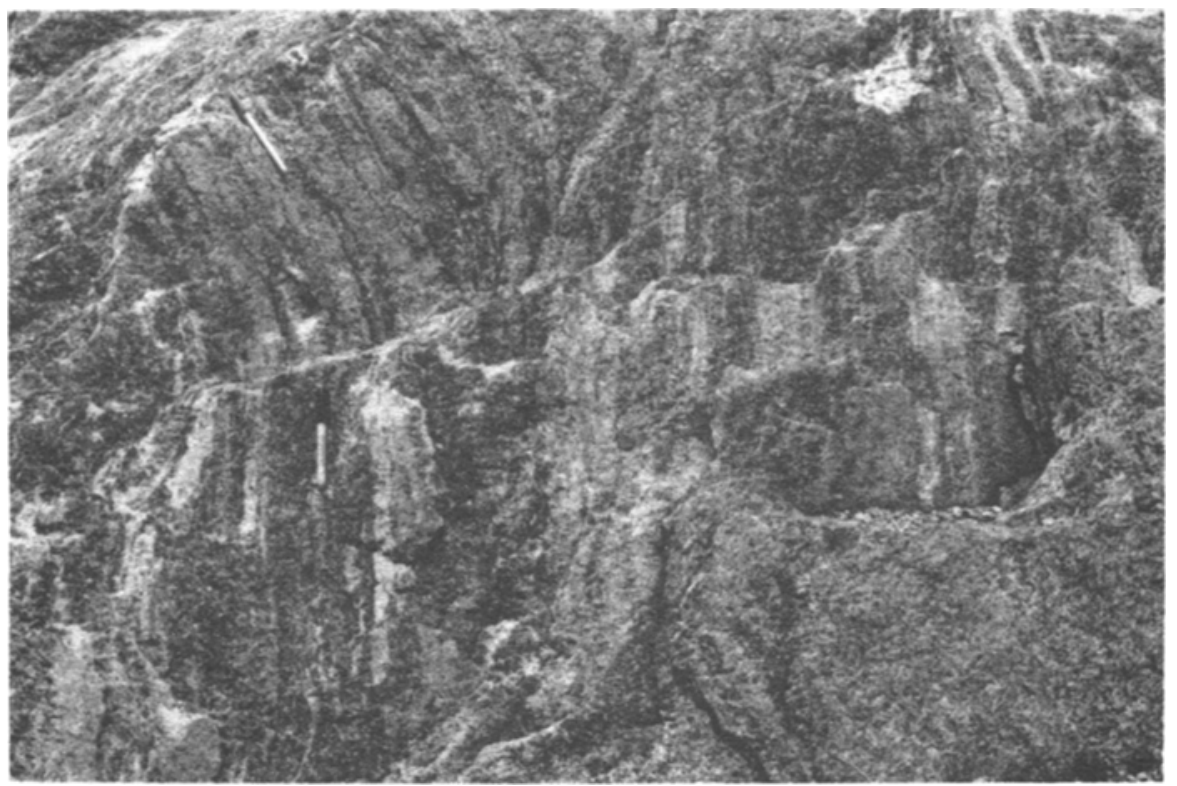

Figure 14. Migmatitic gneiss with striping lineation (paralleled by pencils) parallel to axes of isoclinal folds changing in pitch on the foliation plane because of shearing. South of Bhavani on NH47.

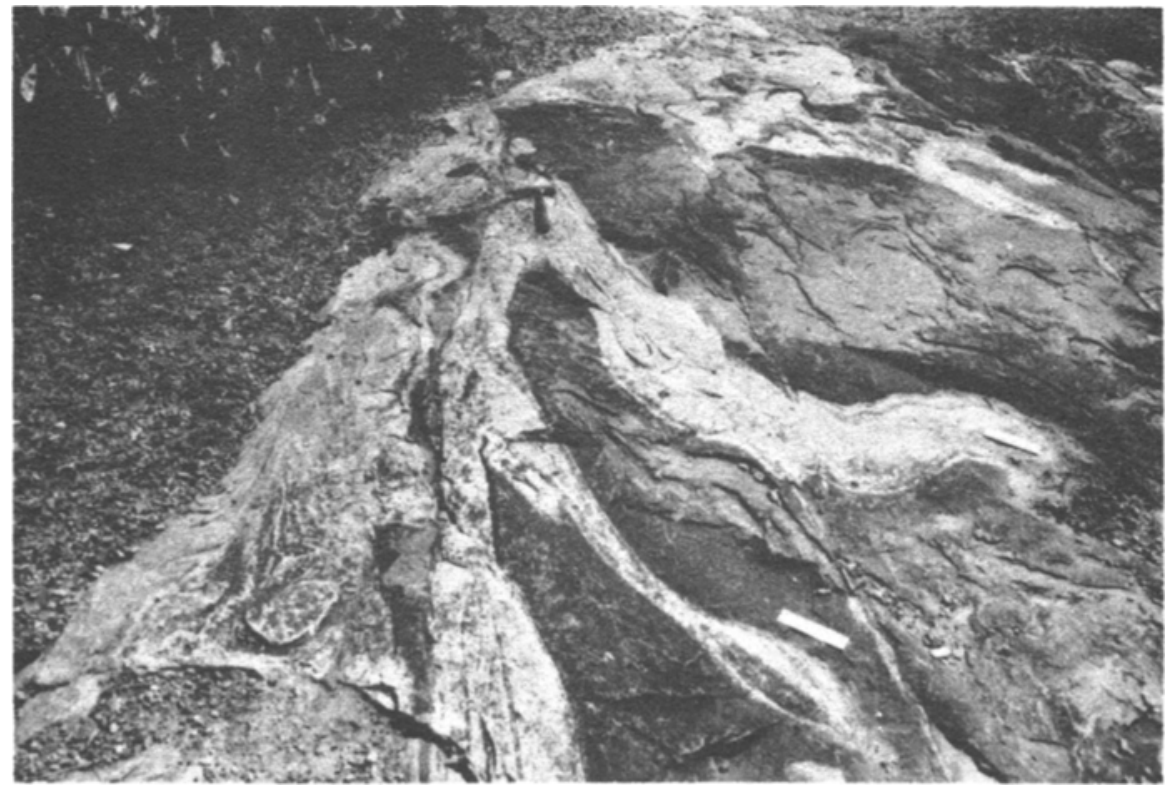

Figure 15. $\mathrm{DhF}_{1}$ isoclinal folds traced by quartzofeldspathic bands in migmatitic gneiss (scales parallel to axial trace) involved in upright folding (hammer handle parallel to axial trace). Sub-horizontal surface, Chandakavadi quarry east of Chamarajnagar. 
with the interpretation of Drury et al (1984), this change in trend can be proved to be due to refolding of the isoclinal folds by near-coaxial $\mathrm{DhF}_{1 a}$ or non-coaxial $\mathrm{DhF}_{2}$ folding. Instructive outcrops in the scale of several tens of metres near Gundlupet and Chamarajnagar show a wide variation in strike of foliation (and axial planes of DhF folds) because of open folding with axial planes striking nearly NS (figure 15).

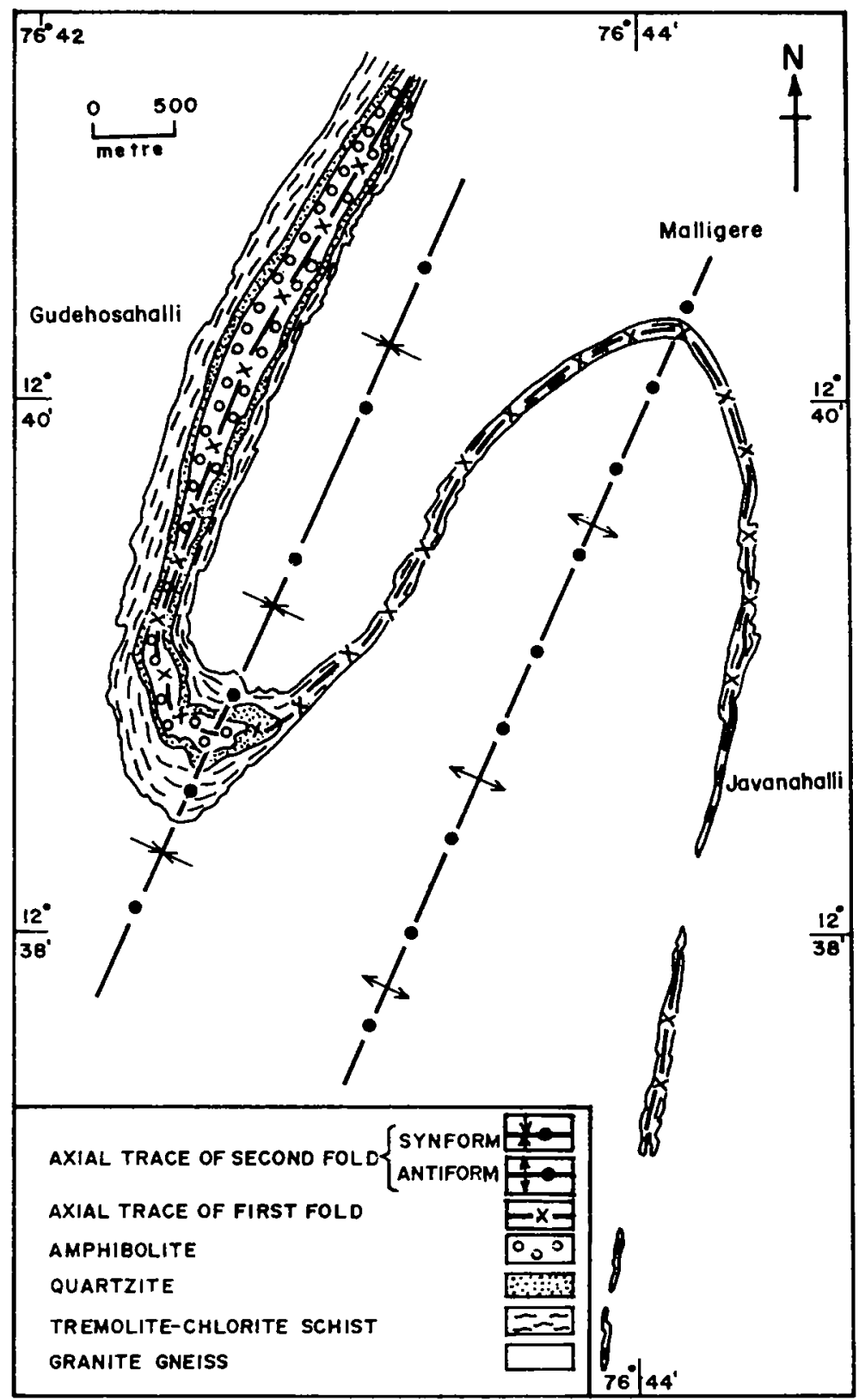

Figure 16. Geological map of the area southeast of Nagamangala showing the large-scale fold pattern (after Naha et al 1995). 
The same variation due to refolding is evident in the Terakanambi area east of Gundlupet in the scale of kilometres (Janardhan et al 1981). That this swing in 'trend' is independent of the Moyar shear zone is proved by the change in 'trend' from nearly EW to nearly NS within a few metres in a number of outcrops near to, as well as tens of kilometres away, from the Moyar shear. For example, within the Moyar shear zone supposedly more than $20 \mathrm{~km}$ in width, strike of foliation ranging widely from nearly NS to EW has been noted in a number of instances. ENE-trending fold axes over an extensive terrane, from near Mettupalaiyam (in the Bhavani shear zone) through Madukkarai to Pollachi and southwestward up to Ottapalam far away from the Moyar and Bhavani shear zones, cannot be an effect of any of the shear zones. Relevant in this context is the similarity in the style and sequence of large-scale structures over several hundred square kilometres north of Mysore (north of the Moyar shear zone) and extensive areas south of the Bhavani shear zone, north and south of Coimbatore. It should be mentioned here that the rock formations north of the Moyar and south of the Bhavani shear zones belong to the supposedly older Archaean supracrustal Sargur Group and Satyamangalam Group respectively, the two being stratigraphically equivalent (Gopalakrishnan et al 1975). Near Nagamangala north of Mysore, supracrustal rocks within the Peninsular Gneiss have been involved in isoclinal folding followed by coaxial refolding (figure 16). Near Madukkarai south of Coimbatore (south of the Bhavani shear) also supracrustal rocks within migmatitic gneisses involved in isoclinal folding have been affected by coaxial refolding (figure 17). Although there is a difference in detail about the structural interpretation, the broad sequence of structures here is similar to that reported by Nair and Nair (1980) from the Ottapalam area in the western part of the Palghat gap. The only structural difference between these two areas intervened by the two shear zones is the orientation of the axial planes and axes of the folds. Whereas near Nagamangala, Chamarajnagar and Sargur areas the 'trend' is

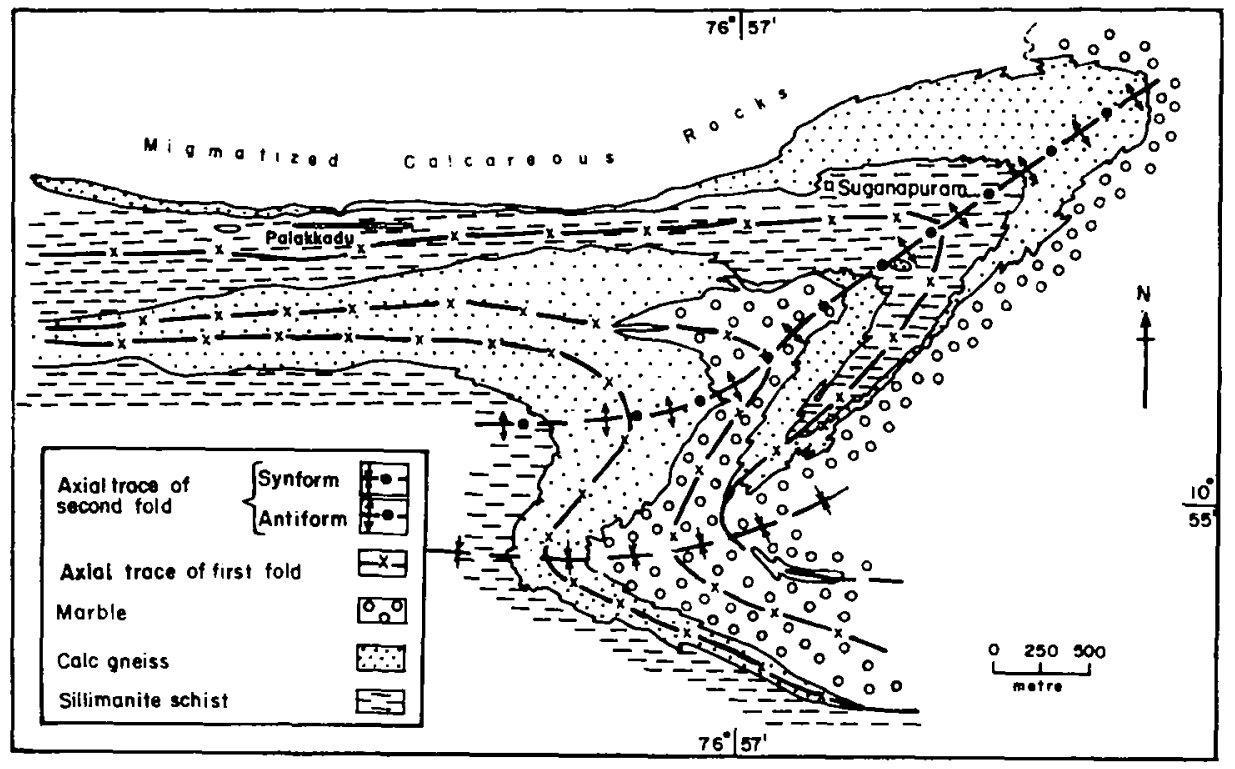

Figare 17. Geological map of the area around Sugunapuram near Madukkarai showing the large-scale fold pattern (mapped by K Naha, R Srinivasan and G K Deb). 
nearly NS, which is also the strike of the later axial planes $\left(\mathrm{DhF}_{2}\right)$, the fold axes and the later axial planes have an east-northeasterly attitude in the Madukkarai area. This variation cannot be explained by reorientation due to dragging along a translational fault zone.

\section{Acknowledgements}

The authors are indebted to the Jawaharlal Nehru Memorial Fund (KN) and the Council of Scientific and Industrial Research, Government of India (KN and RS), for supporting the research project. The Director, Indian Institute of Technology, Kharagpur, and the Director, National Geophysical Research Institute, Hyderabad, are thanked for encouraging this inter-institutional programme. Help from $\mathrm{K}$ Gopalan and B Sreenivas is gratefully acknowledged. Thanks are due to $\mathbf{P} \mathrm{K}$ Banerjee, T Bhattacharya, S A Drury, S K Ghosh, D Mukhopadhyay and M Raith for comments on an early version of the manuscript. However, the authors are solely responsible for the views expressed in the paper.

\section{References}

Chadwick B, Ramakrishnan M, Viswanatha M N and Murthy V S 1978 Structural studies in the Archaean Sargur and Dharwar supracrustal rocks in the Karnataka craton; J. Geol. Soc. India 19 531-539

Drury S A and Holt R W 1980 The tectonic framework of the south Indian craton: A reconnaissance involving LANDSAT imagery; Tectonophysics 65 T1-T15

Drury S A, Harris N B W, Holt R W, Reeves-Smith G J and Wightman R T 1984 Precambrian tectonics and crustal evolution in south India; J. Geol. 92 3-20

Fermor L L 1950 Precambrian formations of India; Geol. Mag. 87 140-144

Ghosh S K and Sengupta S 1987 Progressive development of structures in a ductile shear zone; J. Struct. Geol. 9 277-287

Gopalakrishnan K, Sugavanam E B and Venkata Rao V 1975 Are there rocks older than the Dharwars? A reference to rocks in Tamil Nadu; Indian Mineralogist 16 26-34

Holmes A 1949 The age of uraninite and monazite from the post-Delhi pegmatites of Rajputana; Geol. Mag. 86 288-302

Janardhan AS, Ramachandra H M and Ravindra Kumar G R 1979 Structural history of the Sargur supracrustals and associated gneisses, southwestern part of Mysore, Karnataka; J. Geol. Soc. India 20 61-72

Janardhan A S, Shadakshara Swamy N and Ravindra Kumar G R 1981 Petrological and structural studies of the manganiferous horizons and recrystallized ultramafics around Gundlupet, Karnataka; J. Geol. Soc. India 22 103-111

Mukhopadhyay D 1986 Structural pattern in the Dharwar craton; J. Geol. 94 167-186

Naha K 1964 A critique of 'orogenic trends' in Archaean correlation in India; Tectonophysics $1431-438$

Naha K, Rai Chaudhuri A, Ranjan V and Srinivasan R 1995 Superposed folding in the Honakere arm of the Chitradurga-Karighatta schist belt in the Dharwar tectonic province, southern India, and its bearing on the Sargur-Dharwar relation; Proc. Indian Acad. Sci. (Earth Planet. Sci.) 104 327-347

Naha K, Srinivasan R and Jayaram S 1990 Structural evolution of the Peninsular Gneiss - an Early Precambrian migmatitic complex from south India; Geol. Rundschau 79 99-109

Naha K, Srinivasan R and Jayaram S 1991 Sedimentational, structural and migmatitic history of the Archaean Dharwar tectonic province, southern India; Proc. Indian Acad. Sci. (Earth Planet. Sci.) 100 413-433

Naha K, Srinivasan R and Naqvi S M 1986 Structural unity in the Early Precambrian Dharwar tectonic province, Peninsular India; Q. J. Geol. Mining Met. Soc. India 58 219-243

Nair P K R and Nair E V 1980 Superposed folding of Precambrian rocks around Ottapalam, Palghat district, Kerala; In: Geology and geomorphology of Kerala: Geol. Surv. India spl. publ. 5 15-19 
Narayanaswami S 1970 Tectonic setting and manifestation of the upper mantle in the Precambrian rocks of south India; Proc. Second Symposium on Upper Mantle Project, Hyderabad, 377-403

Radhakrishna B P 1989 Suspect tectono-stratigraphic terrane elements in the Indian sub-continent; J. Geol. Soc. India 34 1-24

Raith M, Srikantappa C, Ashamanjari K G and Spiering B 1990 The granulite terrane of the Nilgiri Hills (south India): characterization of high-grade metamorphism; In: Granulites and crustal evolution (eds) D Vielzeuf and Ph Vidal, 339-365

Ramakrishnan M 1993 Tectonic evolution of the granulite terrain of south India; Geol. Soc. India Mem. 25 35-44

Wise D V, Dunn D E, Engelder J T, Geiser P A, Hatcher R D, Kish S A, Odom A L and Schamel S 1984 Fault-related rocks: suggestions for terminology; Geology 12 391-394 